\title{
Preface to the 1983 Edition
}

For the new edition I have made minor changes in the text and have added a new introduction indicating Afghānī's relationship to later trends in Islamic thought and activity. When footnotes in this book refer to my articles for futher details, the reader should now rather refer to Nikki R. Keddie, Sayyid Jamāl ad-Dinn "alAfghāni"”: A Political Biography (Berkeley and Los Angeles: University of California Press, 1972). The work on the new edition was done while I held Rockefeller Foundation and Woodrow Wilson Center fellowships in 1982 and thanks are due to both of them for giving me the time and assistance to complete this work. Naturally, neither is responsible for what $I$ have written. 
